\title{
PERAN SEL KUPFFER PADA STEATOHEPATITIS ALKOHOL
}

\author{
Lestari B. M. \\ Sunny Wangko \\ Bagian Anatomi-Histologi Fakultas Kedokteran Universitas Sam Ratulangi Manado \\ Email: ttaarriiyy@yahoo.com
}

\begin{abstract}
In chronic alcohol consumption, there is an increase of intestinal mucosa layer permeability. Acetaldehyde, an alcohol metabolite, plays an important role in this change because it causes redistribution of proteins of epithelial junctions from intercellular to intracelullar locations. Therefore, gut permeability increases which leads to an increase of gut endotoxin in the portal vein. This gut endotoxin activates Kupffer cells to produce cytokines, especially TNF- $\alpha$, and reactive oxygen species (ROS). These ROS activate the NF-kB pathway resulting in an increase of TNF- $\alpha$ production. Besides that, in hepatocytes, TNF- $\alpha$ can induce ROS production in mitochondria through an electron transport chain reaction. Either TNF- $\alpha$ or ROS has a high potential to cause liver injuries and inflammations.
\end{abstract}

Key words: Kupffer cells, alcohol, liver, endotoxin

\begin{abstract}
Abstrak: Pada konsumsi alkohol kronis terdapat peningkatan permeabilitas mukosa usus. Asetaldehid (metabolit alkohol) berperan penting terhadap perubahan tersebut karena bahan ini menyebabkan redistribusi protein-protein taut epitelial dari intersel ke intrasel. Peningkatan permeabilitas usus berlanjut dengan peningkatan kadar endotoksin (yang berasal dari usus) dalam darah portal. Endotoksin ini akan mengaktivasi sel Kupffer untuk memroduksi sitokin, terutama TNF- $\alpha$, dan reactive oxygen species (ROS). Selanjutnya ROS akan mengaktivasi jalur NF-kB, yang menghasilkan peningkatan produksi TNF- $\alpha$. Selain itu pada hepatosit TNF- $\alpha$ dapat menginduksi produksi ROS mitokondria melalui rantai transpor elektron. Baik TNF- $\alpha$ maupun ROS sangat potensial menyebabkan cedera dan inflamasi hati.
\end{abstract}

Kata kunci: sel Kupffer, alkohol, hati, endotoksin

Minuman beralkohol sering dijumpai dalam kehidupan sehari-hari. Mengonsumsi alkohol berlebihan dan berkepanjangan dapat mengakibatkan terganggunya organorgan penting dalam tubuh, salah satunya yaitu hati. Telah diketahui bahwa hati mempunyai fungsi penting yaitu sebagai pusat pengatur metabolisme dalam tubuh dan juga sebagai pendetoksifikasi endotoksin dan eksotoksin. ${ }^{1-3}$

Tidak kurang dari 320.000 orang berusia 15-29 tahun yang meninggal setiap tahun karena berbagai penyebab terkait alkohol (WHO 2011) ${ }^{1}$ dan sekitar 2,5 juta per tahun untuk semua usia. ${ }^{4}$ Di Indonesia sendiri, rata-rata konsumsi alkohol sebanyak 2,50 liter (WHO 2005). ${ }^{4}$ Di Sulawesi Utara khususnya daerah Manado, dari hasil pemantauan penulis sendiri jumlah pengkonsumsi alkohol sangat banyak.

Salah satu penyakit yang dapat ditimbulkan dari konsumsi alkohol yang berlebihan ialah steatohepatitis. Steatohepatitis adalah perlemakan hati yang merupakan kondisi reversibel dimana trigliserida lemak terakumulasi dalam sel-sel hati melalui proses steatosis dan disertai dengan peradangan progresif hati (hepatitis). Steatohepatitis bisa juga dijumpai pada obesitas.

Patogenesis steatohepatitis berhubung- 
an erat dengan stres oksidatif dan peroksidasi lemak yang terkait dengan perlemakan hati, endotoksemia, aktivasi sel stelata, dan jaring sitokin yang kompleks yaitu tumor necrosis factor- $\alpha$ (TNF- $\alpha$ ). Studi morfologi klasik steatohepatitis alkohol mengemukakan hipotesis bahwa limfosit dan makrofag (sel Kupffer) berperan penting dalam patogenesis penyakit tersebut. $^{6}$

Sel-sel Kupffer mempunyai reseptor permukaan untuk immunoglobulin (Ig). Seperti makrofag umumnya, sel Kupffer mampu berespon terhadap rangsangan inflamasi dengan menyekresikan sitokin yaitu TNF- $\alpha$, interleukin-1 (IL-1) dan kompleks antigen-antibodi, serta mempunyai kemampuan fagositik untuk mencerna mikroorganisme dan debris sel. Adanya infiltrasi makrofag ke jaringan hati menunjukkan terjadinya peradangan dengan gradasi tertentu pada jaringan tersebut. ${ }^{7-10}$

\section{HATI}

Hati merupakan organ terbesar dalam tubuh manusia. ${ }^{2}$ Hati dibungkus oleh simpai tipis jaringan ikat (kapsula Glisson) yang menebal di hilus tempat vena porta dan arteri hepatika memasuki hati. ${ }^{3}$ Satuan struktural hati disebut lobulus hati. Komponen struktural utama hati ialah hepatosit (sel hati) (Gambar 1). Sel-sel tersusun membentuk lempeng-lempeng yang saling berhubungan. Celah di antara lempeng ini mengandung kapiler, yaitu sinusoid hati. ${ }^{11-13}$

Sinusoid dipisahkan dari lempeng hepatosit oleh celah Disse yang mengandung mikrovili hepatosit sehingga cairan darah dengan mudah mengalir dan berkontak langsung dengan permukaan hepatosit. Hal ini memudahkan pertukaran makromolekul dari lumen sinusoid ke hepatosit dan sebaliknya. ${ }^{8,12}$

Di dalam celah Disse (celah perisinusoid) terdapat sel Ito (sel penimbun lemak) yang mengandung inklusi lemak yang kaya vitamin A, sedangkan di dalam sinusoid ditemukan sejenis fagosit yaitu sel Kupffer. Sel ini berasal dari monosit sirkulasi dan termasuk dalam sistem fagosit mononuklear. ${ }^{8,11}$

Jaringan hati menerima darah dari dua sumber yaitu dari arteri hepatika $(25 \%)$ dan vena porta $(75 \%)$ sehingga semua bahan yang diabsorpsi melalui usus akan mencapai hepar kecuali chyle. ${ }^{3,8}$ Fungsi utama sirkulasi hati dilakukan oleh sinusoid dengan permukaan yang luas untuk pertukaran metabolisme dari darah dan parenkim hati. ${ }^{14}$ Darah yang mengalir melalui hati membawa bahan makanan berserta bahan toksik yang terkandung di dalamnya. Bahan toksik ini akan diekskresikan bersama dengan empedu. ${ }^{14}$

\section{SEL KUPFFER}

\section{Asal sel Kupffer}

Sama dengan makrofag umumnya, sel Kupffer juga berasal dari hematopoiesis sumsum tulang, dimana promonosit berproliferasi dan berdiferensiasi menjadi monosit yang beredar di dalam darah. Proses hematopoiesis ini dikendalikan oleh antara lain interleukin 3 (IL-3), macrophage colony stimulating factor (M$\mathrm{CSF})$ dan gra-nulocyte and macrophage colony stimulating factor (GM-CSF). ${ }^{3,15}$ Monosit darah telah memiliki aktivasi migrasi, kemotaksis, pronositosis dan fagositosis, serta reseptor untuk IgE, Fc (Fc $\gamma \mathrm{R})$ dan komplemen iC3b. Dalam proses migrasi ke jaringan-jaringan, monosit mengalami proses diferensiasi lebih lanjut. Monosit yang bermigrasi ke jaringan hati akan berdiferensiasi menjadi sel Kupffer. ${ }^{15-17}$

\section{Histofisiologi sel Kupffer}

Sel Kupffer adalah salah satu sel stelata yang ditemukan pada permukaan luminal sel-sel endotel dalam sinusoid dan mencakup $15 \%$ dari populasi sel-sel hati. Di dalam jaringan hati sel Kupffer terdistribusi pada tiga zona yaitu: 1) zona periportal, 2) zona tengah (midzonal), dan 3) zona perisentral. ${ }^{18,19}$ Sebagian besar selsel tersebut berada di daerah periportal lobulus hati, yang merupakan tempat perlangsungan fagositosis yang sangat aktif. 
Sel-sel Kupffer yang telah aktif mampu memfagositosis sel-sel lain dan partikel asing. $5,11,12$

Sel Kupffer berukuran besar dengan sitoplasma bercabang dan batas sel tidak teratur (Gambar 1). Dahulu sel ini disebut juga sel stelata retikuloendotelial. Oleh karena kerja fagositosisnya maka inti sering tampak tertutup oleh partikelpartikel yang difagositosisnya., ${ }^{9,13}$

Morfologi dan biokapasitas sel Kupffer di daerah periportal berbeda dengan yang di daerah tengah dan peri-sentral. Sel Kupffer di daerah periportal lebih besar sehingga memungkinkan aksi fagositosis yang lebih aktif, sedangkan yang di daerah perisentral mungkin lebih aktif dalam produksi sitokin. ${ }^{9}$ Sebelum masuk ke sirkulasi umum, darah portal harus terlebih dulu melintasi sinusoid hati yang dilapisi oleh sel-sel Kupffer. Sel-sel ini akan memfagositosis bakteri, virus, partikel asing maupun bahan toksik yang terdapat dalam darah. Bila tidak terdapat partikel asing dalam darah, maka sel Kupffer berada dalam keadaan istirahat. ${ }^{2,7}$

Sel Kupffer dapat diaktivasi oleh berbagai molekul, termasuk endotoksin bakteri. Sel Kupffer yang teraktivasi akan mengeluarkan berbagai sitokin, termasuk TNF- $\alpha$ dan beberapa jenis interleukin.
Semua molekul dapat bertindak sebagai sitokin proinflamasi, yaitu merangsang respon inflamasi yang diperlukan untuk melenyapkan molekul toksik atau molekul asing dan juga sesegera mungkin memulai proses penyembuhan. ${ }^{9,10,20}$

\section{Aktivasi sel Kupffer oleh endotoksin}

Telah lama diketahui bahwa makrofag yang diisolasi dari wilayah anatomis yang berbeda menunjukkan keanekaragaman kemampuan dan fenotip. Heterogenitas makrofag ini dapat berasal dari kondisi khusus masing-masing jaringan-jaringan. Sel Kupffer mampu mengeluarkan sitokin yang dapat mengatur fungsi sel-sel lain yang terlibat dalam respon imun (efek parakrin). ${ }^{11,15,20}$

Alkohol dapat menyebabkan peningkatan kadar endotoksin dalam darah dan hati. ${ }^{20}$ Pada hewan coba tikus yang mengonsumsi alkohol dalam jumlah banyak akan terjadi peningkatan permeabilitas mukosa usus sehingga memungkinkan masuknya berbagai molekul, termasuk endotoksin usus ke dalam darah. ${ }^{21}$ Peningkatan permeabilitas ini disebabkan oleh asetildehid, yaitu metabolit paling beracun dalam metabolisme etanol yang dihasilkan oleh kerja enzim alcohol dehydrogenase $(\mathrm{ADH}) \mathrm{di}$ mukosa usus dan bakteri usus. ${ }^{22}$

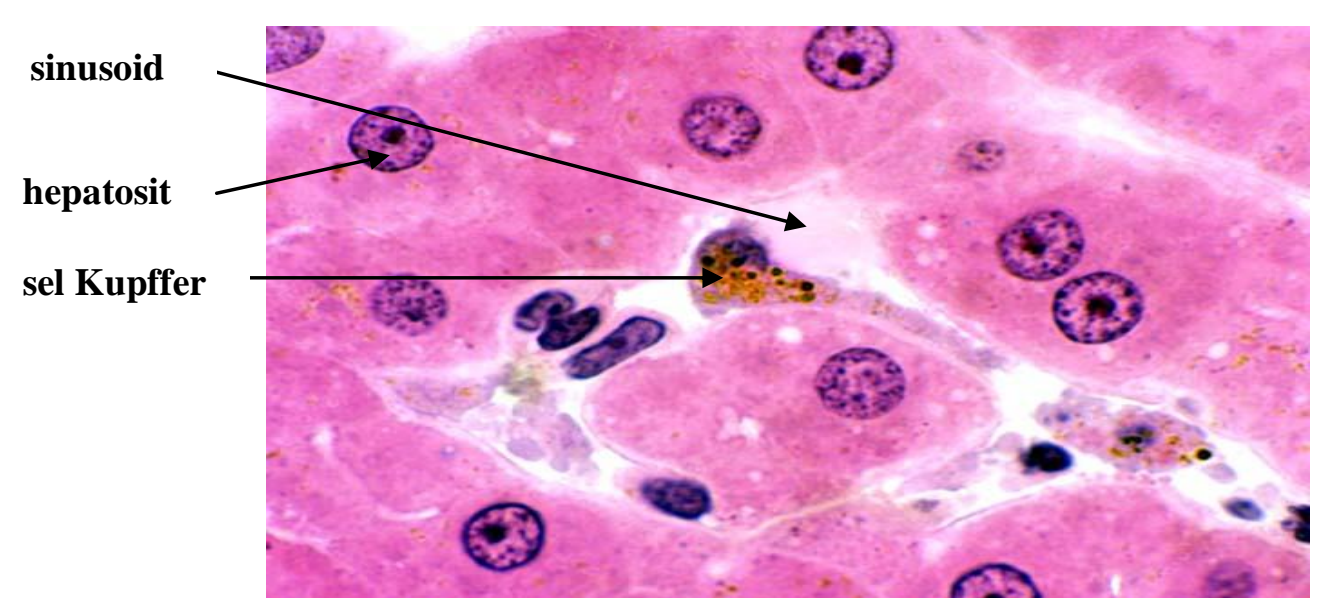

Gambar 1: Di dalam sinusoid terdapat sel Kupffer (makrofag) yang akan memfagositosis partikel yang melewati sinusoid (terutama bakteri dan sel darah yang sudah tua). Partikel pigmen kecoklatan di dalam sel Kupffer berasal dari sel-sel rusak yang difagositosis; dapat berupa lipofuscin atau hemosiderin. Sumber: Caceci, 2000. ${ }^{13}$ 
Studi pada koloni sel epitel usus selapis (Caco-2 cell monolayer) meneliti mekanisme asetildehida meningkatkan permeabilitas mukosa usus yang dikaitkan dengan terjadinya redistribusi protein taut sekap (occludin dan ZO-1/zona occludens-1) dan taut lekat (E-cadherin dan $\beta$-catenin) dari tautan intersel ke kompartemen intrasel. Asetildehida dapat meningkatkan fosforilasi tirosin pada ZO-1, E-cadherin dan $\beta$ catenin dengan umpan baliknya menyebabkan penurunan aktifitas protein tyrosine phosphatase (PTP) yaitu PTP1B (97\%) dan sebagian PTP1C dan PTP1D, tanpa mempengaruhi aktivitas tirosin kinase. Hal ini menunjukkan bahwa asetaldehid menghambat PTP untuk meningkatkan fosforilasi tirosin protein taut sekap dan taut lekat, yang dapat berakibat disrupsi tautan tersebut oleh karena redistribusi proteinnya. Interaksi antara PTP1B bersama dengan $E$ cadherin dan $\beta$-catenin sangat penting bagi organisasi taut sekap dan taut lekat serta pemeliharaan barier epitel usus. Asetildehid menyebabkan terganggunya interaksi antara $E$-cadherin, $\beta$-catenin dan PTP1B karena penurunan aktifitas PTP1B, yang berakibat peningkatan permeabilitas mukosa usus. ${ }^{22}$

Sel Kupffer dapat diaktifkan oleh endotoksin bakteri penghuni usus tertentu. Bakteri mati akan melepaskan endotoksin yang masuk ke aliran darah dan kemudian berinteraksi dengan sel Kupffer di hati. Sel Kupffer akan teraktivasi melalui interaksi dengan molekul kompleks protein yang terletak di luar sel atau molekul yang berhubungan langsung ke dalam sel. Sel Kupffer yang teraktivasi menghasilkan superoksida dan TNF- $\alpha$; kedua bahan ini dapat mengakibatkan kerusakan jaringan hati (Gambar 2). ${ }^{20}$

Telah diidentifikasi protein CD14 yang terletak di bagian luar setiap sel Kupffer dan tidak mencapai membran interior sel. Protein ini berfungsi sebagai reseptor endotoksin agar dapat mengaktifkan sel Kupffer. Aktivasi ini melibatkan transmisi sinyal dari luar ke dalam sel Kupffer, yang memicu berbagai reaksi biokimia. $^{20}$

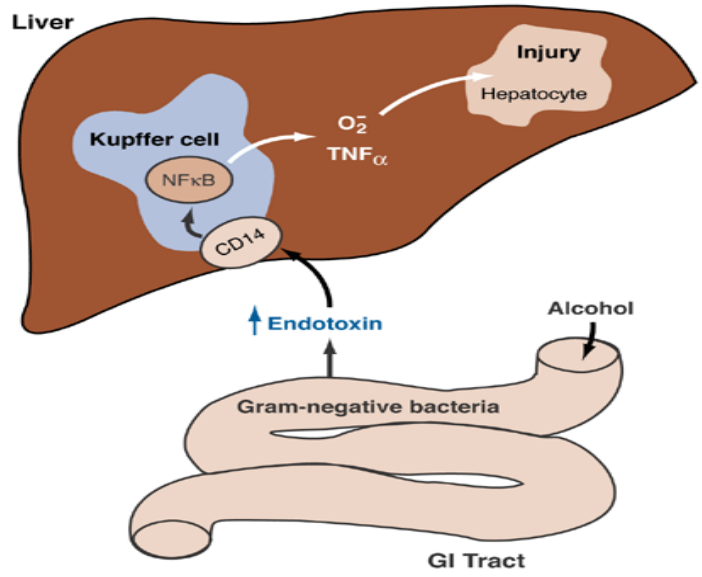

Gambar 2. Hubungan antara pelepasan endotoksin, aktivasi sel Kupffer dan cedera hati. Pada konsumsi alkohol kronis, endotoksin bakteri usus mengaktifkan sel Kupffer hati melalui interaksi dengan molekul CD14 yang terletak di permukaan sel. Interaksi ini mengakibatkan produksi nuclear factor kappa $B$ (NFkB) yang mengarahkan ke pembentukan sejumlah besar faktor sitotoksik, yaitu radikal superoksid $\left(\mathrm{O}_{2}\right)$ dan sitokin (terutama TNF- $\alpha$ ). Sumber: Wheeler, 2004..$^{20}$

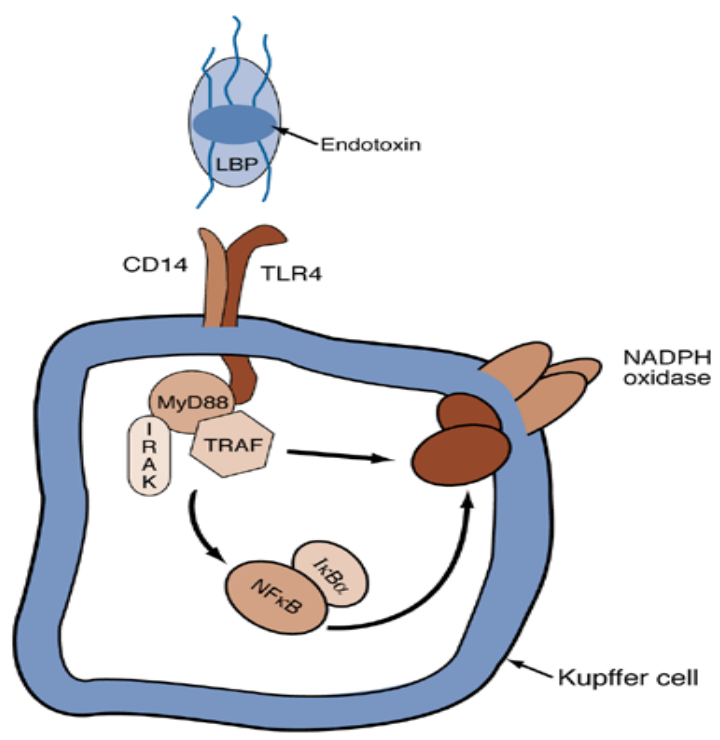

Gambar 3. Mekanisme endotoksin mengaktifkan sel-sel Kupffer dalam hati. Endotoksin berikatan dengan LPS-binding protein terlarut, kemudian berinteraksi dengan kompleks reseptor (CD14 dan TLR4). Interaksi ini menyebabkan aktivasi molekul NF-кB di dalam sel, yang selanjutnya akan menghasilkan superoksida melalui kompleks NADPH oksidase dan produksi sitokin. Sumber: Wheeler, $2004 .^{20}$ 
Selain itu, endotoksin harus berinteraksi dengan reseptor lain yang dapat mengirimkan sinyal sampai ke dalam sel Kupffer yaitu toll-like receptor (TLR), khu-susnya TLR4. ${ }^{20}$ Juga dibutuhkan LPSbinding protein (LBP) yang berfungsi sebagai reseptor struktural endotoksin, mengikat endotoksin dan kemudian menempelkannya ke sel Kupffer. Endotoksin kemudian dapat berinteraksi dengan TLR4, dan interaksi ini menghasilkan sinyal yang ditransmisikan oleh TLR4 ke dalam sel Kupffer (Gambar 3). ${ }^{20}$

Jumlah CD14 pada permukaan sel-sel Kupffer tidak tetap. Dengan tercetusnya banyak rangsangan termasuk endotoksin dapat terjadi peningkatan kadar CD14. Pada manusia dengan kondisi hati normal, sel Kupffer hanya memiliki molekul CD14 yang relatif sedikit, tetapi jumlah ini akan meningkat pada berbagai inflamasi hati. ${ }^{20}$

\section{Gangguan hati akibat konsumsi alkohol kronis}

Konsumsi alkohol kronis dapat mengakibatkan berbagai gangguan hati yaitu: steatosis hati (perlemakan hati) (80\%), steatohepatitis alkoholik (10-35\%), sirosis $(10 \%)$, dan karsinoma hepatoselular. ${ }^{21,23,24}$ Steatosis hati dapat berkembang menjadi steatohepatitis yaitu steatosis yang disertai dengan peradangan hati dimana terjadi apoptosis dan nekrosis hepatosit. ${ }^{25,26}$

Secara makroskopik, pada alkoholisme kronis hati tampak lunak, kuning, dan berlemak, serta terjadi pembengkakan jaringan hati dan penambahan berat hingga 4-6 kg. Pada awal penyakit, biasanya fibrosis tidak ada atau sedikit, namun seiring dengan berlanjutnya asupan alkohol maka akan terbentuk jaringan fibrosa disekitar vena sentralis dan meluas ke dalam sinusoid di dekatnya. Proses perlemakan dapat pulih sempurna jika asupan alkohol dihentikan. ${ }^{23,24}$

Secara mikroskopik, sitoplasma sel-sel yang terkena tampak bervakuola yang terlihat pada perubahan hidrofik, tetapi isi vakuola ialah lemak dan bukannya air. Di hati, lemak yang tertimbun intrasel sering relatif banyak sehingga inti sel terdesak ke satu sisi dan sitoplasma ditempati oleh satu vakuola berisi lemak. ${ }^{6,23}$ Kriteria histopatologik untuk diagnosis steatohepatitis menekankan pada adanya infiltrasi neutrofil. Perubahan patologik yang paling jelas di hati saat terpapar alkohol tampak pada hepatosit. Hepatosit normal cukup resisten terhadap apoptosis yang diinduksi TNF- $\alpha$, tetapi hepatosit pada hewan coba tikus dengan perlemakan hati akan cepat nekrosis setelah terpapar TNF- $\alpha$ meskipun hanya dalam jumlah kecil. ${ }^{6,26,27}$

\section{Interaksi antara sel Kupffer, alkohol, oksidan dan TNF- $\alpha$ pada steatohepatitis (penyakit hati alkoholik)}

Salah satu komponen utama jaringan hati yang berperan pada penyakit hati alkoholik ialah sel Kupffer yang teraktivasi oleh endotoksin. Umumnya hanya sejumlah kecil endotoksin yang diserap dari usus melalui lapisan mukosa usus ke vena portal, yang kemudian dibawa ke hati dan mengaktifkan sel-sel Kupffer untuk memulai proses inflamasi hati. Konsumsi alkohol berlebihan yaitu $80 \mathrm{gr} / \mathrm{hari}$ ( 8 botol bir atau 7 ons minuman keras berkadar $80 \%$ ) dapat menyebabkan peningkatan kadar endotoksin dalam darah dan hati akibat terjadinya peningkatan permeabilitas mukosa usus melalui kerja asetildehid. ${ }^{22,27}$

Translokasi produk bakteri dari lumen usus ke sirkulasi mesenterika dan limfatik juga dapat menginduksi produksi TNF- $\alpha$ dan sitokin proinflamasi lainnya seperti IL1, IL-6, dan IL-8 baik secara regional oleh sel Kupffer maupun sistemik. ${ }^{20,22,23}$ Selain itu sel Kupffer yang teraktivasi juga menghasilkan superoksida melalui jalur NADPH oksidase, yang bersama-sama TNF- $\alpha$ dapat mengakibatkan kerusakan jaringan hati (Gambar 2, 3). ${ }^{20,22,27}$

Alkohol secara langsung bersifat toksik terhadap jaringan hati karena alkohol dapat menyebabkan stres oksidatif di jaringan tersebut. Etanol dimetabolisme di hati, dapat larut baik dalam air maupun lemak serta dapat menyebar cepat melalui mukosa esofagus dan usus. Terdapat tiga 
jalur metabolisme etanol dalam tubuh manusia yaitu oksidasi etanol, transpor elektron secara mikrosomal, dan katalisis etanol; ketiga jalur ini melibatkan enzim alkohol dehidrogenase. Masing-masing jalur bisa menghasilkan radikal bebas yang memengaruhi sistem antioksidan. ${ }^{28}$ Pada metabolisme etanol secara mikrosomal dan mitokondria dapat terjadi produksi reactive oxygen species (ROS) seperti anion superoksida $\left(\mathrm{O}_{2}^{-}\right)$dan $\mathrm{H}_{2} \mathrm{O}_{2}$ yang merupakan penyebab penting terjadinya stres oksidatif. Sitokrom P450 isoform 2E1 yang diinduksi oleh konsumsi etanol kronis secara bermakna akan meningkatkan pembentukan ROS di dalam mitokondria. Enzim sistemik sitokrom P450 (CYP) 2E1 terlibat sebagai sumber $\mathrm{O}_{2}{ }^{-}$dan $\mathrm{H}_{2} \mathrm{O}_{2}$ dalam hepatosit selama keracunan etanol. $\mathrm{H}_{2} \mathrm{O}_{2}$ akan meng-hasilkan radikal hidroksil yang sangat reaktif sehingga dapat mencederai jaringan hati. $^{28,29}$

Oksidan dapat mengaktifkan protein regulator nuclear factor kappa $B$ (NF-kB). Umumnya NF-kB terdapat dalam bentuk terikat dengan inhibitornya yaitu inhibitor kappa $B$ (IkB) di dalam sitoplasma. IkB terikat dengan dimer protein P50/P65. Stimulasi oksidan dapat memicu perubahan dalam sel yang mengakibatkan fosforilasi IkB. Aktivasi NF-kB melibatkan fosforilasi cepat dan pembelahan proteolitik IkB; IkB terlepas dari dimernya P50/P65, dan NF-kB akan bermigrasi ke inti sel dan mengikat DNA sehingga memulai proses transkripsi. $^{27,30} \mathrm{NF}-\kappa \mathrm{B}$ merupakan pengatur unsur gen dari beberapa sitokin proinflamasi seperti TNF- $\alpha$ dan IL-1. Dengan demikian, produksi ROS yang mengaktifkan NF- $\kappa \mathrm{B}$ dapat meningkatkan produksi TNF- $\alpha$ (Gambar 4)..$^{31,32}$ ROS yang berlebihan di dalam sel dan juga kurangnya molekulmolekul yang dapat menghilangkan ROS seperti antioksidan dapat mengakibatkan stres oksidatif yang dapat merusak sel. Salah satu jenis ROS yang penting adalah superoksida. Pada hewan coba tikus (telah dilakukan penghambatan terhadap NADPH oksidase) yang diberi alkohol kronis terbukti dapat mengurangi stres oksidatif, dan kurangnya stres oksidatif juga akan mengurangi produksi TNF- $\alpha{ }^{20}$

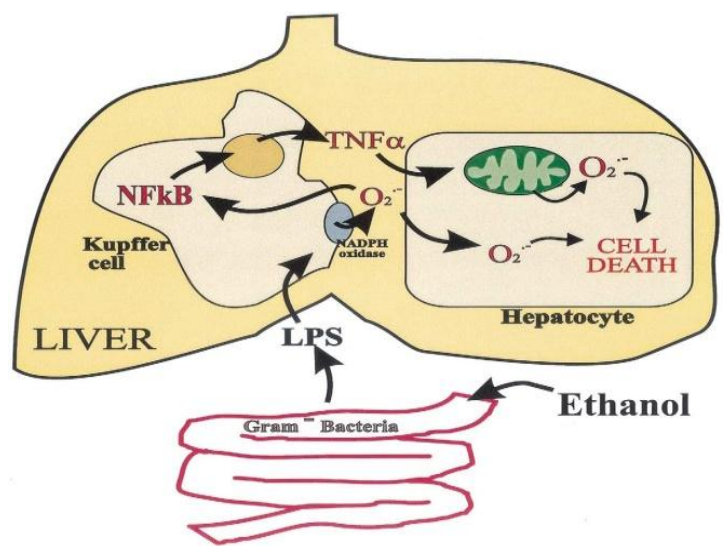

Gambar 4. Etanol mengubah permeabilitas lapisan mukosa usus sehingga endotoksin mudah masuk ke dalam darah. LPS dapat mengaktifkan sel Kupffer jika berikatan dengan CD14 dan TLR4, sehingga menghasilkan superoksida melalui enzim NADPH oksidase. Superoksida akan menyebabkan pengaktifan NF-kB sehingga terjadi peningkatan produksi TNF- $\alpha$. Selanjutnya TNF- $\alpha$ juga merangsang produksi oksidan di dalam mitokondria sel hati melalui penghambatan transpor elektron. Sumber: Wheeler, 2001. ${ }^{31}$

Kono et al, meneliti kerja oksidan pada perjalanan steatohepatitis yang diinduksi alkohol. ${ }^{31}$ Hewan coba tikus diberi antioksidan dipheylene iodium (DPI) yang merupakan inhibitor NADPH oksidase. Pada tikus yang diberi DPI terbukti bahwa antioksidan ini dapat mencegah steatohepatitis yang diinduksi etanol. Hal ini disebabkan oleh penghambatan pembentukan radikal bebas melalui jalur NADPH oksidase yang mencegah aktivasi NF-kB dan ekspresi TNF- $\alpha$ di hati, disertai penurunan produksi sitokin lainnya. ${ }^{28,31}$ Alopurinol yang merupakan inhibitor xanthine oksidase dapat juga dipertimbangkan oleh karena terdapat sejumlah kecil radikal bebas terbentuk melalui jalur xanthine oksidase selain melalui jalur NAPH oksidase. $^{27,28,31}$ Ebselen ialah organoselenium yang secara klinis biasanya digunakan pada pengobatan stroke, namun dapat juga diberikan pada steatohepatitis karena terbukti 
dapat melindungi cedera hati yang diinduksi etanol. Hal ini menunjukkan bahwa antioksidan memiliki efek protektif terhadap cedera hati. ${ }^{28,31}$

Pada steatosis terjadi peningkatan sintesis asam lemak di hati. Hal ini diawali olah kerja TNF- $\alpha$ yang merangsang lipolisis di jaringan perifer sehingga terjadi peningkatan asam lemak bebas (free fatty acid, FFA) dalam sirkulasi. ${ }^{26}$ TNF- $\alpha$ juga dapat meningkatkan produksi trigliserida di hati akibat migrasi FFA dari jaringan adiposa ke hati sehingga terjadi hiperlipidemia. TNF- $\alpha$ dapat mempercepat perkembangan steatosis hati. Pada steatohepatitis alkohol didapatkan peningkatan ekspresi TNF- $\alpha$ dalam hati dan peningkatan konsentrasi $\mathrm{TNF}-\alpha$ plasma. TNF $-\alpha$ juga dapat merangsang sintesis free fatty acid (FFA) di hati melalui peningkatan sterol regulatory element binding protein-1c (SREBP-1c) yaitu pengatur sintesis asam lemak di hati dan fatty acid synthase (FAS) yaitu enzim yang mengkatalisis asam lemak rantai panjang melalui kondensasi acetil-CoA dan malonyl-CoA. SREBP-1c merupakan faktor transkripsi yang mengaktifkan gen enzim yang mengatur biosintesis kolesterol dan asam lemak. SREBP-1c dapat meningkatkan transkripsi gen yang terkait dengan sintesis asam lemak, termasuk FAS. Mekanisme kerja TNF- $\alpha$ dalam menyebabkan steatosis yaitu TNF- $\alpha$ meningkatkan regulasi SREBP-1c, kemudian SREBP-1c akan mentranskripkan FAS yang merupakan faktor sintesis asam lemak di hati. ${ }^{33,34}$ Bila terpapar etanol baik akut maupun kronis TNF- $\alpha$ dapat meningkatkan pembentukan ROS di mitokondria hepatosit melalui rantai transpor elektron sehingga memperparah kerusakan jaringan hati. ${ }^{25}$

Dalam hal pencegahan steatohepatitis dapat dipertimbangkan untuk menekan pertumbuhan bakteri gram negatif usus agar tingkat endotoksin plasma menurun. Juga dengan terpeliharanya integritas mukosa usus maka transfer endotoksin dari usus ke sirkulasi dapat dihalangi. Cedera hati yang diinduksi etanol akan menurun jika mikroflora gram negatif dihilangkan dari usus dengan pemberian bakteri probiotik seperti Lactobacillus. $^{22}$ Pada hewan coba tikus yang mengonsumsi Lactobacillus terbukti dapat mengurangi tingkat endotoksin dan keparahan cedera hati. Bakteri probiotik yang paling banyak menghuni usus kecil ialah spesies Lactobacilli GG sedangkan di usus besar terutama Bifodobacteria. Kedua jenis bakteri ini bermanfaat untuk menekan pertumbuhan bakteri gram negatif, produksi endotoksin. ${ }^{22,23,28}$ Untuk pemeliharaan permeabilitas usus dapat diberikan EGF, Lglutamine, gandum, atau $\mathrm{Zn}$ sehingga dapat menekan transfer endotoksin usus ke sirkulasi. $^{22}$

\section{SIMPULAN}

Konsumsi alkohol kronis dan berlebihan dapat menyebabkan kelainan hati, salah satunya yaitu steatohepatitis. Pada konsumsi alkohol kronis terjadi peningkatan permeabilitas usus sehingga endotoksin usus mudah masuk ke aliran darah yang kemudian dapat mengaktifkan sel Kupffer. Bila teraktivasi, sel Kupffer akan memroduksi berbagai sitokin, salah satunya yang sangat penting yaitu TNF- $\alpha$, dan reactive oxygen species; keduanya merupakan pemicu berbagai jenis proses inflamasi pada hati.

\section{DAFTAR PUSTAKA}

1. VOA NEWS. Konsumsi alkohol naik di negara berkembang [homepage on the Internet]. Nodate [Cited 2011 Apr 6]. Available from: URL: http://www. voanews.com/indonesian/news/1167589 09.html

2. Pearce EC. Anatomi dan Fisiologi untuk Paramedis. Alih Bahasa: Handoyo. Jakarta: Gramedia Pustaka Utama, 2008; p.202-6.

3. Setiadi. Anatomi dan Fisiologi Manusia. Yogyakarta: Graha Ilmu, 2007; p.77, 80-1, 244.

4. WHO. Global status report on alcohol and health. 2008;2-7.

5. Fatty liver [homepage on the Internet]. Nodate [cited 2011 Mar 8]. Available from: URL: http://en.wikipedia.org/ 
wiki/Fatty_liver

6. Lefkowitch JH, Haythe JH, Regent N. Kupffer cell aggregation and perivenuler distribution in steatohepatitis. Mod Pathol. 2002;15:699-704.

7. Bevelander G, Ramaley JA. Essential of Histology. Alih Bahasa: Gunarso W (Edisi Kedelapan). Jakarta: Erlangga, 1998; p. 177-8.

8. Wangko S. Hepar sebagai kelenjar saluran cerna, kajian histofisiologik. BIK Biomed. 2008;4:135-42.

9. Ibelgaufts $H$. Cytokines \& cells on pathfinder encyclopedia: Kupffer cells [homepage on the Internet]. Nodate [cited 2011 Feb 4]. Available from: URL: http://www.copewithcytokines. de/cope.cgi?key=Kupffer\%20cells

10. Knights K. What are Kupffer cells? [homepage on the Internet]. Nodate [cited 2011 Jan 10]. Available from: URL: http://www.wisegeek.com/whatare-kupffer-cells.htm

11. Junqueira LC, Carneiro J. Histologi Dasar. Alih Bahasa: Tambajong J (Edisi Kesepuluh). Jakarta: EGC, 2007; p.31923, 235-347.

12. Eroschenko VP. Atlas Histologi dengan Kolerasi Fungsional. Alih Bahasa: Tambajong J. Jakarta: EGC, 2003; p. 215-9.

13. Caceci T. Accessory glands of the digestive tract [homepage on the Internet]. Nodate [Cited 2000 May 5]. Available from: URL: http://education. vetmed.vt.edu/curriculum/VM8054/Lab s/Lab20/Lab20.htm

14. Ahmad. Liver detoxification [homepage on the Internet]. Nodate [Cited 2006 Mar 2]. Available from: URL: http://pure-detox.blogspot.com/2006/03/ liver-detoxification.html

15. Lesson CR. Textbook of Histology. Alih Bahasa: Siswojo (Edisi Pertama). Jakarta: Binarupa Aksara, 1996; p.117-8.

16. Gordon S, Taylor PR. Monocyte and macrophage heterogeneity. Nat Rev Immunol. 2005;5:953-64.

17. Mosser DM. The many faces of macrophage activation. J Leukoc Biol. 2003;73:209-12.

18. Martinez FO, Gordon S, Locati $M$, Mantovani A. Transcriptional profiling of the human monocyte-to-macrophage differentiation and polarization. $\mathbf{J}$ Immunol. 2004;25:277-86.

19. Vollmar B, Menger $M$. The hepatic microcirculation: mechanistic contributions and therapeutic targets in liver injury and repair. Physiol Rev. 2009;89:1285-8.

20. Wheeler M. Endotoxin and Kupffer cell activation in alcoholic liver disease [homepage on the Internet]. Nodate [cited 2004 Oct 4]. Available from: URL:

http://pubs.niaaa.nih.gov/publications/ar h27-4/300-306.htm

21. Tilg H, Diehl AM. Cytokines in alcoholic and nonalcoholic steatohepatitis. NEJMI. 2000;343:1467-76.

22. Purohit V, Bode JC, Bode C, Brenner DA, Choudry MA, Hamilton F, et al. Alcohol, intestinal bacterial growth, intestinal permeability of endotoxin, and medical consequences. Pubmed. 2008; 42:349-61.

23. Kumar V, Cortan RS, Robbins SL. Buku Ajar Patologi. Alih Bahasa: Pendit B (Edisi Ketujuh). Jakarta: EGC, 2007; p.684-9.

24. Price SA, Wilson LM. Patofisiologi konsep klinis proses-proses penyakit. Alih Bahasa: Pendit B (Edisi Keenam). Jakarta: EGC, 2006; p.45-6.

25. Hart C.L. Effect of body mass index and alcohol consumption on liver disease. BMJ. 2011;340:1-7.

26. Pinto HC. Alterations in liver ATP homeostasis in human nonalcoholic steatohepatitis. JAMA. 1999;282:16591664.

27. Kono H, Rusyn I, Uesegi T, Yamashina S, Connor HD, Dikalova A, et al. Diphenyleneiodonium sulfate, an NADPH oxidase inhibitor, prevents early alcohol-induced liver injury in the rat. Am J Physiol Gastrointest Liver Physiol. 2001;280:1005-12.

28. Das SK, Vasudevan DM. Alcoholinduced oxidative stress. Life Sci. 2007; 81:177-187.

29. Albano E. Alcohol, oxidative stress and free radical damage. Nutrition Society. 2006;65:279-90.

30. Packer L. NFkB activation [homepage on the Internet]. Nodate [cited $2001 \mathrm{Feb}$ ]. Available from: URL: http:// 
www.thaiuwave.com/networkkantioxida nts/nfkb.htm

31. Wheeler MD, Kono H, Yin M, Nakagami M, Uesugi T, Arteel GE, et al. The role of Kupffer cell oxidant production in early ethanol-induced liver disease. Free Radical Biology \& Medicine. 2001; 31:1544-49.

32. Neuman GM. Cytokines-central factors in alcoholic liver disease. National Institute on Alcohol Abuse and Alcoholism. 2003;27:306-16.

33. Endo M, masaki T, Seike M, Yoshimatsu
H. TNF- $\alpha$ induced hepatid steatosis in mice by enchancing gene expression of sterol regulatory element binding protein-1c. Society for Experimental Biology and Medicine. 2007;2016-21.

34. Tomita K, Azuma T, Kitamura N, Tamiya G, Ando S, Nagata $H$, et al. Leptin deficiency enhances sensitivity of rats to alcoholic steatohepatitis through suppression of metallothionein. Am J Physiol Gastrointest Liver Physiol. 2004;287:1078-85. 